\title{
Efeitos da adição de batata na silagem de capim-elefante sobre o consumo e a produção em vacas leiteiras ${ }^{1}$
}

\section{Valdir Botega Tavares ${ }^{2}$, José Cardoso Pinto ${ }^{3}$, Adauto Ferreira Barcelos ${ }^{4}$, Joel Augusto Muniz ${ }^{5}$, Adauton Vilela Rezende ${ }^{6}$, José Rodolfo Reis de Carvalho ${ }^{7}$}

\author{
1 Pesquisa financiada pela FAPEMIG. \\ 2 Programa de Pós-graduação em Zootecnia da Universidade Federal de Lavras (UFLA). \\ ${ }^{3}$ Departamento de Zootecnia da UFLA. \\ ${ }^{4}$ Empresa Pesquisa Agropecuária de Minas Gerais, EPAMIG. \\ 5 Departamento de Ciência Exatas da UFLA. \\ ${ }^{6}$ Departamento de Zootecnia da UNIFENAS \\ 7 Curso de Graduação em Zootecnia da UFLA.
}

RESUMO - Objetivou-se com este trabalho avaliar a produção e a composição do leite em vacas alimentadas com silagens contendo batata. Foram selecionadas 12 vacas: 9 delas com 50 a 70 meses de idade e 3 de 36 a 42 meses, lactantes, com peso aproximado de $550 \mathrm{~kg}$. O delineamento experimental foi em três quadrados latinos $4 \times 4$, composto de quatro períodos experimentais e quatro tratamentos (silagens): silagens de milho (SM); capim-elefante (SC); capim-elefante com 7\% de batata (SC 7\%); e capim-elefante acrescido de 14\% de batata (SC14\%). Os animais que receberam as dietas com SM, SC 14\% e SC 7\% apresentaram ingestões mais altas de MS em comparação àqueles que ingeriram dietas à base de silagem de capim-elefante puro. O fornecimento de silagem de capim-elefante formulada com 14\% de resíduo de batata proporcionou aos animais maior produção de leite e de leite corrigida para 3,5\% de gordura, kg de gordura, kg de proteína, kg de sólidos totais, kg de extrato seco desengordurado (ESD) e kg de lactose em comparação à adição de 7\% de batata. A silagem de milho foi superior às demais, pois promoveu maior produção de leite, em kg de proteína, kg de ESD e kg de lactose. A silagem de capim-elefante foi inferior às demais para as produções de ESD e de lactose. Não houve diferença entre as silagens para os teores de gordura, proteína, sólidos totais, ESD, lactose e N-ureico no leite - NUL (mg/dL). A adição de 14\% de resíduo de batata em silagens de capimelefante melhora a ingestão de MS e as produções de leite e leite corrigida para 3,5\% de gordura.

Palavras-chave: gordura do leite, produção de leite corrigida para 3,5\% de gordura, proteína do leite, sólidos totais

\section{Effects of addition of potato in elephant-grass silage on intake and production of dairy cows}

\begin{abstract}
The objective of this study was to evaluate production and composition of milk from cows fed silages containing potato. Twelve females were selected: nine between 50 and 70 months of age and three between 36 and 42 months of age, lactating, with approximate weight of $550 \mathrm{~kg}$. The experimental design consisted of 12 cows in three $4 \times 4$ Latin Squares, with four experimental periods and four treatments: silages of corn (CS); elephant grass (ES); elephant grass activated with 7\% potato residue (ES7\%) and elephant grass activated with 14\% potato residue (ES14\%). The animals submitted to the diets with the silages CS, ES 14\% and ES 7\% presented greater ingestions of DM than those that ingested diets based on silage of pure elephant grass. Supply of diet of elephant grass silage with addition of $14 \%$ potato residue presented greater production of milk and milk corrected for $3.5 \%$ fat, $\mathrm{kg}$ of fat, $\mathrm{kg}$ of protein, $\mathrm{kg}$ of total solids, $\mathrm{kg}$ of degreased dry extract and $\mathrm{kg}$ of lactose compared with the addition of $7 \%$ potato. The corn silage was superior to the others in production of milk, $\mathrm{kg}$ of protein, $\mathrm{kg}$ of degreased dry extract (DDE) and $\mathrm{kg}$ of lactose. Elephant grass silage presented smaller production than the other silages for kg of DDE and lactose. There was no difference between treatments for fat contents, protein, total solids, DDE, lactose, or milk urea$\mathrm{N}$ (mg/dL). The addition of $14 \%$ of potato residue in the elephant grass silage improves ingestion of DM and production of milk.
\end{abstract}

Key Words: milk fat, milk production corrected for 3.5\% fat, milk protein, total solids

\section{Introdução}

A utilização de subprodutos agroindustriais na alimentação do gado leiteiro pode ser uma alternativa para solucionar questões ambientais e econômicas e apresenta ainda vantagens, pois, como diminui a dependência dos bovinos por cereais, pode reduzir o custo total de produção. 
Os subprodutos que podem e são utilizados na alimentação de ruminantes são numerosos. Entre eles, o resíduo agrícola de batata (Solanum tuberosum L.), ou batata diversa, pode ser mais uma alternativa, por conter $57 \%$ de amido na matéria seca e ser produzido em grande quantidade.

O termo batata diversa é uma denominação usada para a batata imprópria para o comércio, mas não para o consumo, ou seja, aquele produto que não alcança os padrões de comercialização, como tamanho e qualidade dos tubérculos, em decorrência da colheita e do beneficiamento. Segundo informações da Associação Brasileira dos Bataticultores, as perdas nesses processos variam de 15 a $20 \%$ da produção, o que representou em 2008 de 169 a 225 mil toneladas de batata diversa em Minas Gerais.

A batata diversa in natura apresenta alto percentual de deterioração em ambientes quentes, tornando difícil a manutenção de suas qualidades bromatológicas por períodos superiores a uma semana. Possivelmente, melhor alternativa consiste na utilização de alguma forma de conservação, como a desidratação, para posterior obtenção do farelo, que pode ser armazenado por mais tempo e usado como aditivo para silagens de gramíneas perenes.

$\mathrm{O}$ alto teor de amido do resíduo de batata quando adicionado na ensilagem eleva o valor nutritivo da silagem, principalmente em carboidratos solúveis e carboidratos totais (amido). O amido é um dos componentes das dietas de vacas de leite e contribui com 60 a 70\% da energia líquida utilizada para produção de leite em sistemas intensivos. Os carboidratos são as maiores fontes de energia para vacas leiteiras, mas são precursores de três importantes componentes do leite: lactose, gordura e proteína. A composição química e as características físicas e cinéticas da digestão dos carboidratos afetam a ingestão de MS, a digestão e a utilização da dieta total e dos nutrientes na glândula mamária para que ocorra satisfatória síntese do leite (Andrade, 2002).

Objetivou-se com este trabalho avaliar a ingestão de MS, a produção e a composição do leite de vacas alimentadas com silagens de capim-elefante contendo batata.

\section{Material e Métodos}

O trabalho foi conduzido nas instalações da Fazenda Experimental da EPAMIG, localizada no município de Três Pontas, Minas Gerais. O experimento foi iniciado na segunda semana do mês de março de 2007 e se estendeu até a quarta semana do mês de maio do mesmo ano.

O delineamento experimental foi constituído de 12 vacas em três quadrados latinos $4 \times 4$; um grupo homogêneo de quatro vacas constituíram-se nas colunas e os períodos de observação nas linhas. As 12 vacas foram selecionadas de um rebanho de 50 vacas e agrupadas nos quadrados latinos de acordo com a ordem de lactação e a produção de leite nos dias anteriores ao início do período préexperimental.

Os períodos experimentais tiveram duração de 21 dias cada. O período pré-experimental, de adaptação dos animais, foi composto de 14 dias, logo após um período de coleta de sete dias. Após cada rodada do tratamento, foram repetidas todas as atividades, com novos sorteios dos tratamentos dentro de cada quadrado latino.

Foram selecionadas 12 vacas holandesas puras de origem, sendo nove com 50 a 70 meses e três com 36 a 42 meses, lactantes, com peso aproximado de $550 \mathrm{~kg}$. Foram levados em consideração o número de dias de lactação (acima de 80 dias) e a produção em torno de 25 kg de leite/dia.

No início e ao final de cada período experimental, os animais foram pesados. O peso foi aferido com uso de uma balança. Os animais foram alojados em tietall, com comedouro, cocho de sal e água individualizados.

Foram utilizadas as três silagens de capim-elefante: uma controle e duas acrescidas de batata diversa, na forma de farelo, e uma silagem de milho: $\mathrm{SM}$ = silagem de milho (padrão); SC = silagem de capim-elefante (controle); SC 7\% = silagem de capim-elefante $+7 \%$ de batata; SC $14 \%$ = silagem de capim-elefante $+14 \%$ de batata (Tabelas 1 e 2 ).

No momento da confecção das silagens com resíduo de batata, as carretas que transportavam o material volumoso foram pesadas para determinação do peso do material e cálculo da quantidade de batata a ser adicionada. O capimelefante foi distribuído no comprimento total do silo, em camadas de $30 \mathrm{~cm}$, seguido de distribuição do aditivo e misturado com auxílio de um garfo, para se obter uma mistura homogênea do material. As silagens foram armazenadas em silos do tipo superfície com capacidade para 15 toneladas.

As dietas foram calculadas de acordo com o NRC (2001) para atender às exigências de vacas adultas com peso vivo médio de 550 kg, não-gestantes, com produção de leite de $25 \mathrm{~kg} /$ dia, com 3,5\% de gordura e sem nenhum ganho de peso. Durante o período experimental, a precipitação pluviométrica foi em torno de $50 \mathrm{~mm}$ e a temperatura média esteve abaixo de $24^{\circ} \mathrm{C}$. Formularam-se as dietas, mantendo a mesma quantidade de FDN, oriunda de forragem em todos os tratamentos, somente variando a FDN de fonte nãoforrageira (caroço de algodão). Foi necessária a correção do déficit proteico da ração. As diferenças entre as silagens utilizadas foram corrigidas com ureia. 
Tabela 1 - Composição bromatológica das silagens e do resíduo de batata

\begin{tabular}{|c|c|c|c|c|c|}
\hline \multirow[t]{2}{*}{ Variável } & \multicolumn{5}{|c|}{ Tratamento } \\
\hline & $\begin{array}{l}\text { Silagem de } \\
\text { milho }\end{array}$ & $\begin{array}{c}\text { Silagem de } \\
\text { capim-elefante }\end{array}$ & $\begin{array}{c}\text { Silagem de } \\
\text { capim-elefante } 7 \%\end{array}$ & $\begin{array}{c}\text { Silagem de } \\
\text { capim-elefante } 14 \%\end{array}$ & Batata \\
\hline Matéria seca, \% & 27,5 & 25,00 & 32,5 & 37,8 & 85,2 \\
\hline $\mathrm{pH}$ & 3,75 & 4,2 & 3,89 & 3,95 & - \\
\hline $\mathrm{N}-\mathrm{NH}_{3} *$ & 4,5 & 9,88 & 6,5 & 5,32 & - \\
\hline Proteína bruta, \% MS & 7,5 & 5,8 & 6,8 & 7,6 & 12,64 \\
\hline Fibra em detergente neutro, \% MS & 54,5 & 73,9 & 68,6 & 57,1 & 13,91 \\
\hline Fibra em detergente ácido, \% MS & 31,0 & 42,0 & 38,0 & 33,0 & 6,55 \\
\hline Extrato etéreo, \% MS & 3,4 & 1,9 & 3,0 & 3,2 & 3,88 \\
\hline Amido, \% MS & - & - & - & - & 58,6 \\
\hline DIVMS, \% & 73,7 & 65,34 & 68,84 & 72,77 & 89,86 \\
\hline Cálcio, \% MS & 0,3 & 0,33 & 0,27 & 0,25 & 0,13 \\
\hline Fósforo, \% MS & 0,2 & 0,27 & 0,26 & 0,22 & 0,18 \\
\hline
\end{tabular}

SC = silagem de capim-elefante (0, 7 e 14\% de batata); DIVMS = digestibilidade in vitro da matéria seca.

$* \mathrm{~N}-\mathrm{NH}_{3}$ como \% do $\mathrm{N}$ total.

Tabela 2 - Composição das dietas experimentais

\begin{tabular}{|c|c|c|c|c|}
\hline Item & Silagem de capim-elefante & Silagem de milho & Silagem de capim $7 \%$ & Silagem de capim $14 \%$ \\
\hline Volumoso (kg/dia) & 32,20 & 40,00 & 26,90 & 27,80 \\
\hline Polpa de citros (kg/dia) & 6,50 & 3,10 & 5,70 & 3,70 \\
\hline Milho (kg/dia) & 2,50 & 2,50 & 2,50 & 2,50 \\
\hline Caroço de algodão (kg/dia) & 2,50 & 2,50 & 2,50 & 2,50 \\
\hline Farelo de soja (kg/dia) & 2,90 & 2,90 & 2,90 & 2,90 \\
\hline Sal branco (kg/dia) & 0,07 & 0,07 & 0,07 & 0,07 \\
\hline Ureia (kg/dia) & 0,15 & 0,10 & 0,12 & 0,09 \\
\hline Premix mineral e vitamínico (kg/dia) & 0,30 & 0,30 & 0,30 & 0,30 \\
\hline Ingestão de MS (\%) & 21,2 & 21,2 & 21,2 & 21,2 \\
\hline Proteína bruta $(\%)$ & 16,3 & 16,4 & 16,01 & 16,3 \\
\hline Nutrientes digestíveis totais (\%) & 68,64 & 71,27 & 69,24 & 71,16 \\
\hline FDNf (\%) & 28,3 & 28,3 & 28,3 & 28,3 \\
\hline Cálcio (\%) & 0,85 & 0,70 & 0,82 & 0,73 \\
\hline Fósforo (\%) & 0,37 & 0,40 & 0,39 & 0,40 \\
\hline
\end{tabular}

SM = silagem de milho; SC = silagem de capim-elefante (0, 7 e $14 \%$ de batata); FDNf = fibra em detergente neutro da forragem.

As sobras foram colhidas diariamente, pela manhã, para avaliação da ingestão de MS. O fornecimento das dietas para os animais era calculado para a ocorrência de sobras, $10 \%$ do total fornecido. Nos dias 15 a 21 de cada período, as sobras foram amostradas, congeladas e foi formada uma amostra composta por vaca. Nos mesmos dias, foram colhidas amostras das silagens e dos concentrados. A ingestão de MS foi calculada multiplicando-se a ingestão diária de matéria natural de cada alimento entre os dias 15 e 21 de cada período por seu teor de MS. Desse número foi subtraída a sobra diária de MS.

Os animais foram ordenhados às $6 \mathrm{~h}$ e às $17 \mathrm{~h}$ e foram realizadas pesagens do leite das últimas 14 ordenhas de cada período, ou seja, do $16^{\circ}$ ao $21^{\circ}$ dia. Amostragens do leite foram tomadas individualmente por vaca e por ordenha nas últimas quatro ordenhas de cada período, conforme metodologia utilizada por Reis et al. (2001). A coleta foi feita em tubo coletor de aproximadamente $100 \mathrm{~mL}$ contendo 2-bromo-2-nitropropano-1-3-diol, homogeneizada após 15 minutos e armazenada em geladeira a $15^{\circ} \mathrm{C}$ por 48 horas.
Após esse período, as amostras foram encaminhadas para análises para determinação dos teores de proteína, gordura, lactose e sólidos totais, pelo processo de infravermelho em analisador Bentley 2000 (Bentley Instruments), e nitrogênio ureico, pelo analisador ChemSpec 150 (Bentley Instruments) no Laboratório da Clínica do Leite do Departamento de Zootecnia da Escola Superior de Agricultura Luiz de Queiroz, Universidade de São Paulo.

Os resultados foram analisados utilizando-se o software SISVAR e modelo utilizado foi como segue:

$$
\mathrm{Y}_{\mathrm{ijkl}}=\mu+\mathrm{q}_{\mathrm{i}}+\mathrm{p}_{(\mathrm{i}) \mathrm{j}}+\mathrm{a}_{(\mathrm{i}) \mathrm{k}}+\mathrm{T}_{\mathrm{l}}+\mathrm{q}_{\mathrm{Til}}+\mathrm{e}_{\mathrm{ijkl}} \text {, }
$$

em que $Y_{i j k l}=$ produção do tratamento $\mathrm{i}$, da vaca $\mathrm{k}$, no período $\mathrm{j}$ dentro do quadrado latino $\mathrm{i} ; \mu=$ média geral; $\mathrm{q}_{\mathrm{i}}=$ efeito do quadrado latino $\mathrm{i}$, com i $=123$; $\mathrm{p}_{(\mathrm{i}) \mathrm{j}}=$ efeito do período j dentro do quadrado latino i, com j = 123 4; $\mathrm{a}_{(\mathrm{i}) \mathrm{k}}=$ efeito da vaca k, dentro do quadrado latino i, com i = 123 4; $\mathrm{T}_{1}$ = efeito do tratamento l, com l = 123 4; $\mathrm{q}_{\text {Til }}$ = efeito da interação entre o quadrado latino i, com o tratamento l; $\mathrm{e}_{\mathrm{ijkl}}=$ erro experimental, aleatório, independentemente, com distribuição normal de média zero e variância $\sigma^{2}$. 
As médias dos tratamentos foram comparadas utilizando-se a técnica de contrastes ortogonais com a seguinte estrutura (Tabela 3):

Tabela 3 - Contrastes ortogonais utilizados para determinar as diferenças ocorridas entre os tratamentos relacionados ao período experimental

\begin{tabular}{cc}
\hline Contraste & Contraste \\
\hline $\mathrm{y}_{1}$ & $3 \mathrm{SM} \times(\mathrm{SC}+\mathrm{SC} 7 \%+\mathrm{SC} 14 \%)$ \\
$\mathrm{y}_{2}$ & $2 \mathrm{SC} \times(\mathrm{SC} 7 \%+\mathrm{SC} 14 \%)$ \\
$\mathrm{y}_{3}$ & $\mathrm{SC} 7 \% \times$ SC $14 \%$ \\
\hline
\end{tabular}

SM = silagem de milho; $\mathrm{SC}$ = silagem de capim-elefante (0, 7 e $14 \%$ de batata). Contrastes obtidos a partir das médias das inferências analisadas durante o período experimental.

\section{Resultados Discussão}

Houve efeito significativo das silagens estudadas sobre a ingestão de matéria seca $(\mathrm{P}<0,05)$ para os contrastes $\mathrm{y}_{2} \mathrm{e}$ $\mathrm{y}_{3}$ (Tabela 4). A ingestão de MS observada com o fornecimento da silagem de capim-elefante (SC) foi inferior $(\mathrm{P}<0,05)$ à obtida com a oferta das silagens de capimelefante adicionadas de 7\% e 14\% de batata (SC 7\%, SC14\%). Essa diferença foi da ordem de 4,61 e 9,84\%, respectivamente. Quando fornecida a silagem de capim-elefante contendo $14 \%$ de batata, o consumo foi superior ao observado com a oferta da silagem de capim-elefante com $7 \%$ desse subproduto $(\mathrm{P}<0,05)$, cujo valor foi de $5,49 \%$.

Essas diferenças foram ocasionadas pela adição e pelos níveis de batata na silagem de capim, que proporcionou aumento no teor de matéria seca e diminuição nos teores de
FDN e FDA. Isso comprova que, mesmo com a disponibilidade de FDN de forragem semelhante para todos os tratamentos, ocorreu diferença no consumo, em razão da digestibilidade dessas silagens (Tabela 2).

Não houve efeito significativo $(\mathrm{P}>0,05)$ para o contraste envolvendo a silagem de milho (SM). Uma das hipóteses para a ausência de efeito pode ter sido o fato de que a silagem de milho apresentou baixo teor de matéria seca (27,50\%), inferior ao recomendado (entre 32 e $35 \%$ ), sugerindo que o material foi ensilado antes do ponto ideal de colheita, conforme relatado por Nussio (1991), resultando em uma silagem com menor teor de amido e maior teor de FDN.

Resultados semelhantes aos desta pesquisa foram relatados por Monteils et al. (2002), que, em estudo com dois tipos de silagem (milho e gramínea perene) e dois tipos de concentrados à base de farelo de trigo e batata, observaram que, quando o volumoso foi silagem de milho vs. silagem de gramínea perene, os consumos de MS situaram-se em torno de 19,8 e 17,5 kg/dia, respectivamente.

Jurjanz et al. (1998) também observaram resultados semelhantes aos deste estudo em pesquisa com três níveis de amido (baixo, médio e alto), duas fontes de amido (casca de batata e de cevada) e dois tipos de volumoso (silagem de milho e gramínea perene). A dieta com nível baixo de amido foi constituída de $100 \%$ de silagem de gramínea perene, no nível médio $75 \%$ de silagem de milho e $25 \%$ silagem de gramínea perene, e no nível alto de amido 100\% de silagem de milho. As ingestões de MS e de energia apenas variaram significativamente com baixa concentração de amido, logo,

Tabela 4 - Produção e composição do leite e eficiência alimentar de vacas leiteiras alimentadas com silagem de capim-elefante contendo batata

\begin{tabular}{|c|c|c|c|c|c|c|c|}
\hline \multirow[t]{2}{*}{ Item } & \multicolumn{4}{|c|}{ Tratamento } & \multicolumn{3}{|c|}{ Contraste } \\
\hline & $\begin{array}{l}\text { Silagem } \\
\text { de milho }\end{array}$ & $\begin{array}{c}\text { Silagem de } \\
\text { capim-elefante (SC) }\end{array}$ & $\begin{array}{c}\text { Silagem de } \\
\text { capim-elefante } 7 \%\end{array}$ & $\begin{array}{c}\text { Silagem de } \\
\text { capim-elefante } 14 \%\end{array}$ & $\mathrm{y}_{1}$ & $\mathrm{y}_{2}$ & $\mathrm{y}_{3}$ \\
\hline Ingestão de matéria seca (kg/dia) & 18,12 & 17,39 & 18,23 & 19,29 & $-0,31$ & $-2,74 *$ & $-1,06^{*}$ \\
\hline Produção de leite, PL (kg/dia) & 25,19 & 22,94 & 22,66 & 24,58 & $5,39 *$ & $-1,38$ & $-1,92 *$ \\
\hline PLCG 3,5 (kg/dia) & 23,52 & 22,80 & 21,96 & 24,39 & 1,41 & $-0,75$ & $-2,43 *$ \\
\hline Gordura (kg/dia) & 0,78 & 0,79 & 0,75 & 0,85 & $-0,05$ & $-0,02$ & $-0,1^{*}$ \\
\hline Proteína (kg/dia) & 0,78 & 0,70 & 0,69 & 0,75 & $0,2 *$ & $-0,04$ & $-0,06^{*}$ \\
\hline Extrato seco desengordurado (kg/dia) & 2,11 & 1,90 & 1,90 & 2,06 & $0,47^{*}$ & $0,16 *$ & $0,16^{*}$ \\
\hline Sólidos totais (kg/dia) & 2,89 & 2,71 & 2,65 & 2,88 & 0,48 & $-0,11$ & $-0,23$ \\
\hline Lactose (kg/dia) & 1,11 & 0,99 & 1,00 & 1,09 & $0,25 *$ & $-0,1^{*}$ & $-0,09 *$ \\
\hline Nitrogênio ureico no leite (mg/dL) & 2,96 & 3,12 & 3,04 & 3,21 & $-0,82$ & $-0,01$ & $-0,17$ \\
\hline Gordura (\%) & 3,22 & 3,53 & 3,37 & 3,50 & $-0,74$ & 0,19 & 0,13 \\
\hline Proteína (\%) & 3,15 & 3,10 & 3,10 & 3,10 & 0,15 & 0 & 0 \\
\hline Extrato seco desengordurado (\%) & 8,47 & 8,41 & 8,47 & 8,48 & 0,05 & $-0,13$ & $-0,01$ \\
\hline Sólidos totais (\%) & 12,69 & 13,17 & 12,55 & 12,45 & 0,13 & 1,34 & 0,1 \\
\hline Lactose (\%) & 4,43 & 4,37 & 4,45 & 4,45 & 0,02 & 0,16 & 0 \\
\hline Nitrogênio ureico no leite (\%) & 12,02 & 14,00 & 13,72 & 13,04 & $-4,7$ & 1,24 & 0,68 \\
\hline Eficiência alimentar & 1,30 & 1,32 & 1,20 & 1,26 & 0,12 & 0,18 & 0,06 \\
\hline
\end{tabular}

SM = silagem de milho; SC = silagem de capim-elefante (0, 7 e $14 \%$ de batata).

PLCG = produção de leite corrigida para $3,5 \%$ de gordura.

$\mathrm{y}_{1}, \mathrm{y}_{2}$ e $\mathrm{y}_{3}$ representam os contrastes: $\mathrm{y}_{1}=3 \mathrm{SM} \times(\mathrm{SC}+\mathrm{SC} 7 \%+\mathrm{SC} 14 \%) ; \mathrm{y}_{2}=2 \mathrm{SC} \times(\mathrm{SC} 7 \%+\mathrm{SC} 14 \%) ; \mathrm{y}_{3}=\mathrm{SC} 7 \% \times \mathrm{SC} 14 \%$ 
esse tratamento apresentava 100\% de silagem de gramínea perene. Esses autores relataram consumos mais elevados para os animais alimentados com altos níveis de amido mais casca de batata.

As dietas, contudo, proporcionaram baixa ingestão de MS, que deveria ser em torno de 21,2 kg MS/dia de acordo com o NRC (2001). A baixa ingestão de MS pode ser decorrente da alta inclusão de FDN de forragem na dieta, em torno de 28,3 kg FDNF/dia (Tabela 1). Os animais receberam uma dieta de FDN total igual a 39,3 kg FDN/dia para silagem de milho e silagem de capim-elefante $14 \%$ e 42,2 para silagem de capim-elefante e silagem de capim-elefante $7 \%$. Em geral, no Brasil, as dietas de vacas leiteiras sempre têm alta inclusão de forragem. Segundo Mertens (1994), com altas concentrações de FDN na dieta, o enchimento ruminal limita o consumo, enquanto em baixas concentrações o feedback negativo sobre a ingestão de energia limitaria o consumo. Allen (2000), em análise de 15 estudos, mostrou que aumentos superiores a $25 \%$ na concentração de FDN da dieta estiveram associados a uma diminuição no consumo.

Houve efeito significativo das silagens $(\mathrm{P}<0,05)$ sobre a produção de leite e a produção de leite corrigida para 3,5\% de gordura (Tabela 4). Os animais que receberam as rações experimentais contendo silagem de milho produziram maior quantidade de leite. Ocorreu uma diferença na ordem de $2,53 \mathrm{~kg} /$ dia por vaca entre as produções de leite para a silagem de milho em relação à silagem de capim-elefante com $7 \%$ de batata.

A silagem de capim-elefante com 14\% de batata proporcionou produção de leite próxima, porém inferior, à obtida com a oferta da silagem de milho, com uma diferença de $0,61 \mathrm{~kg} /$ dia (Tabela 4). A semelhança de resultados foi observada também nas análises bromatológicas das silagens, que ficaram bem próximas quanto aos teores de FDN, FDA e DIVMS (Tabela 2).

Houve efeito significativo das dietas à base de silagem de capim-elefante com 14\% de batata, resultando em maior produção de leite em comparação à silagem de capim-elefante com 7\% desse subproduto $(\mathrm{P}<0,05)$ (Tabela 4$)$. Essa maior produção de leite se deve à maior ingestão de matéria seca e maior DIVMS da dieta com silagem de capim-elefante com $14 \%$ de batata em comparação àquela com $7 \%$, que acarretou maior aporte de nutrientes para glândula mamária e maior produção. Miron et al. (2004) utilizaram subprodutos fibrosos (casca de soja e farelo de glúten de milho) na ração de vacas em lactação e observaram aumento na produção de leite. Esses autores argumentam que esses resultados foram obtidos graças ao fornecimento de uma fração fibrosa mais digestível e condições mais favoráveis de fermentação ruminal.
O fornecimento da silagem de capim-elefante promoveu produção de leite igual à obtida com a silagem de capimelefante com 7\% de batata, na ordem de 22,9 e 22,7 kg/dia, respectivamente (Tabela 4). Essa produção foi alta para animais recebendo silagem de capim-elefante pura e isso ocorreu devido ao balanceamento das dietas por FDNf, uma vez que as forrageiras com maior teor de FDN tiveram também menor relação volumoso/concentrado, que é importante para o aumento da produção de leite e da qualidade do leite produzido.

Schneider et al. (1985) também observaram diferenças na produção de leite quando utilizaram farelo de batata ensilado com gramínea e leguminosa, na razão de 7,5\% do peso fresco do farelo, e substituíram 0, 15 e 30\% do milho moído na mistura concentrada. As médias diárias de produção de leite foram de $28,6 \mathrm{~kg}$ para as vacas recebendo silagem com farelo de batata em comparação à de $26,3 \mathrm{~kg}$ para as vacas recebendo silagem sem farelo de batata.

A produção de leite corrigida para 3,5\% de gordura foi maior nos animais alimentados com a dieta à base de silagem de capim-elefante $14 \%$ em comparação àquela com $7 \%$ de batata $(\mathrm{P}<0,05)$, mesmo não havendo diferença no percentual de gordura (Tabela 4). Em função das pequenas diferenças numéricas nos percentuais de gordura do leite, aliados à produção de leite, essas diferenças repercutiram em maiores produções de leite corrigidas para 3,5\% de gordura no caso das dietas à base de silagem de capim-elefante com 14\% de batata.

Houve efeito significativo das silagens sobre a produção de gordura no leite $(\mathrm{P}<0,05)$. $O$ contraste $\mathrm{y}_{3}$ foi significativo e ocorreu uma variação de $0,1 \mathrm{~kg} /$ dia a mais para a dieta à base de silagem de capim-elefante com 14\% de batata em comparação à silagem com 7\% desse subproduto, em decorrência da produção e da pequena diferença numérica na porcentagem de gordura no leite.

A ausência de efeito significativo sobre os teores de gordura do leite $(\mathrm{P}>0,05)$ pode ser atribuída ao incremento de polpa cítrica na dieta desses animais, que foi maior na dieta com silagem de milho (Tabela 1) e também à qualidade da fibra do capim-elefante, que apresenta teores de FDN e FDA superiores ao da silagem de milho. Com isso, pode ter ocorrido um ambiente ruminal mais favorável (Van Soest, 1991), reduzindo a produção de ácidos graxos de cadeia trans que apresentam efeito inibitório sobre a síntese de ácidos graxos de cadeia curta pela glândula mamária (NRC, 2001). A produção desses ácidos graxos ocorre mais intensamente quando o pH ruminal é baixo, dificultando a bio-hidrogenação. Os ácidos graxos de cadeia trans atuam diminuindo a atividade de várias enzimas que participam da 
formação de triglicerídeos no tecido da glândula mamária (estearil CoA desaturase, acetil CoA carboxilase e acil transferase) (Gaynor et al., 1994).

As silagens tiveram efeito significativo $(\mathrm{P}<0,05)$ sobre a quantidade de $\mathrm{PB}$ no leite, que foi maior para a dieta com silagem de milho em comparação àquelas com silagem de capim-elefante com batata. Esse maior teor de proteína observado com o fornecimento da silagem de milho proporcionou maior produção de kg de PB no leite. Quando os animais foram alimentados com a dieta com silagem de capim-elefante com $14 \%$ de batata, a quantidade de proteína no leite foi superior $(\mathrm{P}<0,05)$ àquela obtida com a oferta da dieta com silagem de capim-elefante com $7 \%$ de batata (Tabela 4).

Solomon et al. (2000) observaram aumento no teor de proteína do leite de animais alimentados com ração contendo maior teor de amido. Neste estudo também foi observado esse aumento no teor de proteína da silagem de milho e da silagem de capim-elefante com $14 \%$ de batata, logo essas silagens apresentaram maiores teores de amido em relação àquela com $7 \%$ de batata.

As silagens não tiveram efeito significativo $(\mathrm{P}>0,05)$ sobre os teores de extrato seco desengordurado, lactose e sólidos totais. Os teores de extrato seco desengordurado e sólicos, no entanto, foram influenciados $(\mathrm{P}<0,05)$ por todas as dietas em estudo. Belibasakis \& Tsirgogianni (1996) encontraram $12,15 \%$ de sólidos totais em vacas leiteiras alimentadas com silagem de milho. Bachman (1992) sugere que a ingestão de uma dieta corretamente balanceada tende a elevar a produção de leite sem alterar sua composição. Para que a proporção dos sólidos totais seja mantida, é necessário que todos os precursores de gordura e proteína estejam em proporções otimizadas e balanceadas.

A quantidade diária de lactose no leite dos animais que receberam silagem de milho foi superior $(\mathrm{P}<0,05)$ à obtida com as demais silagens. A dieta à base de silagem de capim-elefante com $14 \%$ de batata proporcionou resultado superior $(\mathrm{P}<0,05)$ ao observado com a oferta de silagem de capim-elefante com 7\% desse resíduo agroindustrial (Tabela 4). A síntese de lactose na glândula mamária depende da disponibilidade de glicose nesse local, a qual é altamente dependente da disponibilidade de precursores gluconeogênicos no fígado, uma vez que não há fluxo líquido positivo de glicose na veia porta, devido ao uso intenso pelos tecidos viscerais (rúmen, intestino, pâncreas e baço) da glicose absorvida no intestino (Huntington, 1997; Theurer et al., 1999). A utilização de fontes de amido com maior degradabilidade ruminal resulta em maior disponibilidade dos principais precursores para a gluconeogênese hepática, o propionato, os aminoácidos e o lactato (Huntington, 1997; Theurer et al., 1999). A utilização de resíduo de batata na silagem de capim, por ter na composição fontes de amido de maior degradabilidade ruminal, pode, portanto, ter aumentado a produção de propionato no rúmen e, consequentemente, a disponibilidade de glicose para a glândula mamária. Isso pode justificar o aumento na produção de lactose à medida que o resíduo de batata foi adicionado na silagem de capim. Valores bastante próximos dos encontrados neste estudo foram relatados por Belibasakis \& Tsirgogianni (1996), que encontraram teores de 4,75\% de lactose no leite de animais alimentados com silagem de milho. Segundo Fredeen (1996) e Peres Junior (2001), como regra geral, a concentração de lactose no leite não pode ser alterada por fatores nutricionais, portanto, não deve ser usada para o monitoramento nutricional de vacas leiteiras, a menos que os animais estejam muito subnutridos.

Eriksson et al. (2003) avaliaram o uso de beterraba forrageira, batata crua e cevada na alimentação de vacas leiteiras e observaram que, em comparação à associação de beterraba e batata, o fornecimento de cevada batata e cevada pura proporcionou a mais 1,7 e 2,3 litros de leite corrigido a 3,5\% de gordura. As concentrações de gordura no leite, lactose e sólidos totais não foram alteradas pelo fornecimento das silagens de capim-elefante com batata, enquanto a de proteína no leite foi moderadamente mais elevada $(P=0,05)$ no tratamento com cevada. As concentrações de lactose de proteína no leite quando fornecidas as silagens com batata foram semelhantes às do presente estudo, ao passo que a de gordura foi maior.

Não houve efeito significativo $(\mathrm{P}>0,05)$ das silagens sobre os teores e a produção de N-ureico do leite. É possível que as concentrações de $\mathrm{N}$-ureico do leite tenham reduzido com a adição de fontes de carboidratos de maior degradação ruminal, como silagens de capim-elefante com $7 \%$ e $14 \%$ de batata, todavia o teor de amido não foi determinado neste trabalho. Os teores de $\mathrm{N}$-ureico no leite permaneceram dentro da normalidade para vacas holandesas. De acordo com Gonzáles et al. (2000), concentrações médias normais para o $\mathrm{N}$-ureico no leite são de $12 \mathrm{mg} / \mathrm{dL}$ a $18 \mathrm{mg} / \mathrm{dL}$ e valores abaixo dessa faixa de variação refletem deficiência proteica ou excesso de carboidratos na dieta, por outro lado, se a média de $\mathrm{N}$-ureico do rebanho estiver acima desses valores, estão ocorrendo perdas energéticas por eliminação de ureia. Os teores de $\mathrm{N}$-ureico no leite deste experimento estão de acordo com as concentrações médias.

Bargo et al. (2003) também não observaram diferenças nas concentrações de $\mathrm{N}$-amoniacal no fluido ruminal de vacas em pastagens recebendo concentrados amiláceos em 
comparação a concentrados ricos em subprodutos fibrosos. Os valores, porém, mantiveram-se abaixo do valor crítico de $19 \mathrm{mg} / \mathrm{dL}$, associado a problemas reprodutivos.

A eficiência alimentar (LCG/CMS) não diferiu ( $\mathrm{P}>0,05)$ entre as silagens em estudo. A maioria dos trabalhos revisados por Theurer et al. (1999) comprovaram melhor eficiência alimentar para a fonte de amido de maior degradabilidade ruminal.

Onwubuemeli et al. (1985) utilizaram resíduo úmido de batata, composto de $60 \%$ de casca de batata, 30\% de tubérculo de batata crua e $10 \%$ de tubérculo cozido em substituição a $0,10,15$ ou $20 \%$ do milho de alta umidade para 32 vacas em lactação e não observaram diferença na eficiência de utilização da MS. As vacas que receberam maiores quantidades de batata tenderam a ganhar mais peso.

\section{Conclusões}

A adição de resíduo de batata na ensilagem de capimelefante melhora a ingestão de matéria seca e, no nível de $14 \%$ de batata, o consumo de matéria seca é superior ao obtido com o nível de 7\%. A produção e composição do leite observada com a adição de $14 \%$ de resíduo de batata na ensilagem de capim-elefante é semelhante à obtida com silagem de milho, enquanto as produções de leite e de leite corrigido para 3,5\% de gordura determinadas com o uso de silagens de capim-elefante e de capim-elefante com $7 \%$ de batata são inferiores.

\section{Referências}

ALLEN, M.S. Effects of diet on short-term regulation of feed intake by lactating dairy cattle. Journal of Dairy Science, v.83, p.1598-1624, 2000.

ANDRADE, G.A. Substituição do milho moído por polpa cítrica no desempenho de vacas em lactação. 2002. 151f. Tese (Doutorado em Zootecnia) - Universidade Federal de Lavras, Lavras.

ASSOCIAÇÃO BRASILEIRA DA BATATA. Desperdício. Batata Show, v.4, n.10, p.42, 2008.

BACHMAN, K.C. Managing milk composition. In: van HORN, H.H.; WILCOX, C.J. (Eds.). Large dairy herd management. Champaign: American Dairy Science Association, 1992. p.110-121.

BARGO, F.; MULLER, L.D.; KOLVER, E.S. Production and digestion of supplemented dairy cows on pasture. Journal of Dairy Science, v.86, n.1, p.1-42, 2003.

BELIBASAKIS, N.G.; TSIRGOGIANNI, D. Effects of niacin on milk yield, milk composition, and blood components of dairy cows in hot weather. Animal Feed Science and Technology, v.64, p.336-346, 1996.

ERIKSSON, T.; MURPHY, M.; CISZUK, P. et al. Nitrogen balance, microbial protein production, and milk production in dairy cows fed fodder beets and potatoes, or barley. Journal of Dairy Science, v.87, p.1057-1070, 2003.

FREDEEN, A.H. Considerations in the milk nutritional modification of milk composition. Animal Feed and Science Technology, v.59, p.185-197, 1996

GAYNOR, P.J.; ERDMAN, R.A.; TETER, B.B. Milk fat yield andcomposition during abomasal infusion of cis or trans octadecenoates in holstein cows. Journal of Dairy Science, v.77, p.157-165, 1994

GONZÁLES, F.H.D.; BARCELOS, J.; PATINO, H.O. et al. Nutrição de ruminantes. Porto Alegre: UFRGS, 2000. 108p.

HUNTINGTON, G.B. Starch utilization by ruminants: from basics to the bunk. Journal of Animal Science, v.75, p.852-867, 1997.

JURJANZ, S.; COLIN-SHOELLEN, O.; GARDEUR, J.N. et al. Alteration of milk fat by variation in the source and amount of starch in a total mixed diet fed to dairy cows. Journal of Dairy Science, v.81, p.2924-2933, 1998.

MERTENS, D.R. Regulation of forage intake. In: FORAGE QUALITY, EVALUATION, AND UTILIZATION, 1994 , Wisconsin. Proceedings... Wisconsin, 1994. p.450-493.

MIRON, J.; YOSEF, E.; ZENOU, A. Feeding behavior and performace of dairy cows fed pelleted nonroughage fiber byproducts. Journal of Dairy Science, v.87, n.5, p.1372-1379, 2004.

MONTEILS, V.; JURJANZ1, S.; COLIN-SCHOELLEN, O. et al. Kinetics of ruminal degradation of wheat and potato starches in total mixed rations. Journal of Animal Science, v. 80 , p.235-241, 2002.

NATIONAL RESEARCH COUNCIL - NRC. Nutrient requirements of domestic animals: nutrient requirements of dairy cattle. 7.ed.rev. Washington, DC: National Academy of Science, 2001. 381p.

NUSSIO, L.G.; CAMPOS, F.P.; PAZIANI, S.F. et al. Volumosos suplementares: estratégias de decisão e utilização. Piracicaba: ESALQ, 2001. 114p.

ONWUBUEMELI, C.; HUBER, J.T.; KING, K.J. et al. Nutritive value of potato processing wastes in total mixed rations for dairy cattle. Journal of Dairy Science, v.68, n.5, p.12071214, 1985.

PERES, J.R.R.J. O leite como ferramenta de monitoramento nutricional. In: GONZALES, F.H.D.; DURR, J.W.; FONATANELLI, R.S. (Eds.)Uso do leite para monitorar a nutrição e o metabolismo de vacas leiteiras. Porto Alegre: UFRGS, 2001. p.30-45.

REIS, R.B.; SAN EMETERIO, F.; COMBS, D.K. Effects of corn particle size and source on performance of lactating cows fed direct-cut grasslegume forage. Journal of Dairy Science, v.84, p.429-441, 2001.

SCHNEIDER, P.L.; STOKES, M.R.; BULL, L.S. et al. Evalution of potato meal as a feedstuff for lactating dairy cows. Journal of Dairy Science, v.68, n.7, p.1738-1743, 1985.

SOLOMON, R.; CHASE, L.E.; BEN-GHEDALIA, D. The effect of nonstructural carbohydrate and addition of full fat extruded soybeans on the concentration of conjugated linoleic acid in the milk fat of dairy cows. Journal of Dairy Science, v.83, p.1322-1329, 2000.

THEURER, C.B.; HUBER, J.T.; DELGADO, E. Invited review: summary of steam-flaking corn or sorghum grain for lactating dairy cows. Journal of Dairy Science, v.82, p.1950-1959, 1999.

VAN SOEST, P.J.; ROBERTSON, J.B.; LEWIS, B.A. Methods for dietary fiber, neutral detergent fiber, and nonstarch polysaccharides in relation to animal nutrition. Journal of Dairy Science, v.74, p.3583, 1991. 